\title{
Sistem Telemetri Kadar Keasaman, Suhu air dan Cahaya Ruang Berbasis NodeMCU ESP 8266 pada Budidaya Tanaman Hidropronik
}

\author{
Danang ${ }^{1}$, Iman Saufik Suasana ${ }^{2}$, Hudha Pratna Safiyan ${ }^{3}$ Nur Cahyo Hendro Wibowo 4 \\ 123Universitas Sains dan Teknologi Komputer \\ ${ }^{4}$ Universitas Islam Negeri Walisongo \\ 1danang@stekom.ac.id, 22saufik@stekom.ac.id, ${ }^{3}$ Hudha@stekom.ac.id, \\ 4nur_cahyo@walisongo.ac.id
}

\begin{abstract}
Plants with hydroponic systems need to be controlled, it is necessary to monitor the degree of acidity of the water, water temperature, and the concentration of water nutrients to avoid a decrease in plant quality, Hydroponics is installed with a microcontroller that is connected to the internet through the Blynk microcontroller application and will send data to the Android smartphone application in real time. The method used in this research is the prototyping method. The Prototype method is a system life cycle method based on the concept of a working model. Measurement of water $p H 6.5$ and the results of real time measurements at 9 o'clock the temperature of $29^{\circ} \mathrm{C}$ and $71 \%$ humidity and measurements at $12 o^{\prime}$ clock the temperature of $33^{\circ} \mathrm{C}$ and $74 \%, 90 \%$ real-time data communication can run well.
\end{abstract}

Keywords: Hydroponics, microcontroller, android, internet.

\begin{abstract}
Abstrak
Tanaman dengan sistem hidroponik perlu terkontrol, diperlukannya pemantauan derajat keasaman air, suhu air, dan kepekatan nutrisi air untuk menghindari penurunan kualitas tanaman, Hidroponik dipasang mikrokontroler yang terhubung ke internet melalui aplikasi blynk mikrokontroler dan akan mengirim data ke aplikasi smartphone android secara realtime. Metode yang digunakan di dalam penelitian ini adalah metode prototyping. Metode Prototype adalah salah satu metode siklus hidup sistem yang didasarkan pada konsep model bekerja (working model). Pengukuran kadar pH air 6,5 dan hasil real time pengukuran saat jam 9 suhu $29^{\circ} \mathrm{C}$ dan kelembaman $71 \%$ dan pengukuran saat jam 12 suhu $33^{\circ} \mathrm{C}$ dan kelembaman $74 \%$, komunikasi data secara realtime $90 \%$ dapat berjalan dengan baik .
\end{abstract}

Kata kunci : Hidroponik, mikrokontroler, android, internet. 
1. PENDAHULUAN

Hidroponik adalah salah satu cara untuk menanam tanpa memerlukan lahan yang luas dan sangat cocok untuk dibudidayakan di daerah perkotaan. Hidroponik merupakan metode untuk menanam tanaman dengan menggunakan media aliran air. Sistem hidroponik tidak memerlukan pestisida beracun sehingga lebih ramah terhadap lingkungan dan tanaman yang dihasilkan jauh akan lebih sehat. Salah satu metode hidroponik yang sering digunakan adalah Deep Flow Technique (DFT). Hidroponik sistem DFT merupakan metode kultur menggunakan aliran air sebagai media dan persediaan nutrisi. Sedangkan itu media tanam yang sering digunakan pada sistem hidroponik DFT adalah rockwool. Rockwool merupakan media anorganik dengan komponen media yang berguna untuk menyerap dan meneruskan air, sehingga mempunyai kapasitas air tinggi yang memungkinkan untuk menyimpan air nutrisi pada sistem hidroponik yang dibutuhkan oleh tanaman untuk tumbuh.

Bercocok tanam dengan cara hidroponik ini perlu penanganan, perawatan dan pemantauan yang lebih dibandingkan dengan bercocok tanam konvensional dengan media tanah, sehingga pemilik perlu untuk memberikan perhatian lebih kepada tanamannya.

Hidroponik yang ada dimasyarakat pada umumnya masih menggunakan sistem manual dan relatif mahal dari segi waktu, antara lain untuk pengukuran kadar asam (pH) dalam air dan mengetahui volume air yang dipakai. Beberapa kendala yang sering di alami para petani hidroponik di antaranya adalah (1) Tanaman dapat kekurangan oksigen terlarut sehingga membuat pertumbuhan tanaman terganggu. (2) Resiko busuk pada akar tanaman karena jumlah air yang terlalu banyak. (3) Dapat terjadi endapan pada pipa menyebabkan banyak masalah yang timbul. (4) Lebih banyak memerlukan nutrisi. Kadar asam $(\mathrm{pH})$ umumnya dapat di ketahui dengan Total Disolved Solids (TDS) meter, dan perlu di lakukan setiap hari.

Berdasakan kendala dan permasalahan yang ada pada metode hidroponik sebagaimana yang telah diuraikan diatas, maka dalam penelitian ini memberikan sebuah solusi untuk membantu menyelesaikan kendala dan permasalahan tersebut dengan memanfaatkan mikrokontroller dan sensor berbasis NodeMCU yang di hubungkan ke smartphone melalui Internet of things (IoT) untuk mengontrol derajat keasaman, volume dan suhu serta nutrisi bisa terserap dengan optimal ke dalam tanaman sehingga para pemilik hidroponik dapat memantau keadaan dan perawatan otomatis tanaman yang sedang dibudidayakan kapanpun dan dimanapun.

\section{METODE}

Metode yang digunakan di dalam penelitian ini adalah metode prototyping. Metode Prototype adalah salah satu metode siklus hidup sistem yang didasarkan pada konsep model bekerja (working model). Tujuannya adalah mengembangkan model menjadi sistem final. Artinya sistem akan dikembangkan lebih cepat dari pada metode tradisional dan biayanya menjadi lebih rendah. Ada banyak cara untuk memprotoyping, begitu pula dengan penggunaannya. Ciri khas dari metodologi ini adalah pengembang sistem (system developer), klien, dan pengguna dapat melihat dan melakukan eksperimen dengan bagian dari sistem komputer dari sejak awal proses pengembangan. 


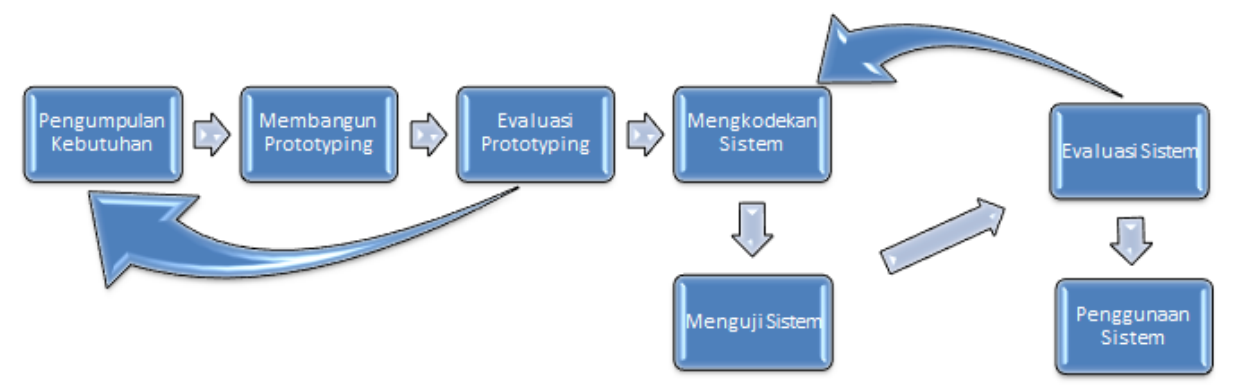

Gambar 1 metode prototyping

Tahapan-tahapan dalam Prototyping adalah sebagai berikut:

a) Pengumpulan kebutuhan Pelanggan dan pengembang bersama-sama mendefinisikan format seluruh perangkat lunak, mengidentifikasikan semua kebutuhan, dan garis besar sistem yang akan dibuat.

b) Membangun prototyping
Membangun prototyping dengan membuat perancangan sementara yang berfokus pada penyajian kepada pelanggan (misalnya dengan membuat input dan format output).

Berikut adalah perancangan blok diagram Sistem Telemetri Kadar Keasaman, Suhu air dan Cahaya Ruang Berbasis NodeMCU ESP 8266 dapat dilihat pada gambar 2 .

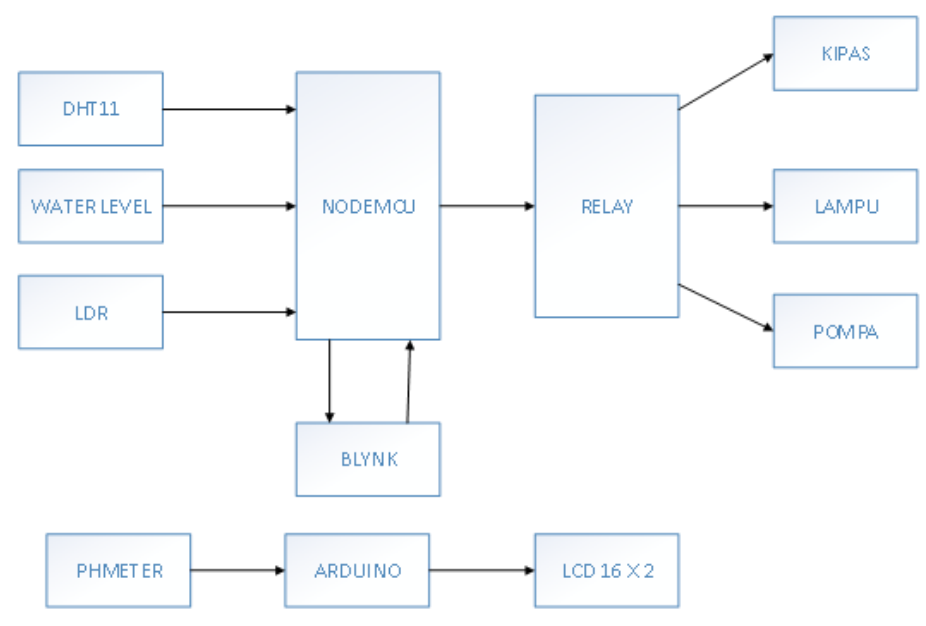

Gambar 2 Blok Diagram

c) Evaluasi protoptyping

Evaluasi ini dilakukan oleh pelanggan apakah prototyping yang sudah dibangun sudah sesuai dengan keinginann pelanggan. Jika sudah sesuai maka langkah 4 akan diambil. Jika tidak prototyping direvisi dengan mengulang langkah 1, 2 , dan 3. d) Mengkodekan sistem

Dalam tahap ini prototyping yang sudah di sepakati diterjemahkan ke dalam bahasa pemrograman yang sesuai.

e) Menguji sistem

Setelah sistem sudah menjadi suatu perangkat lunak yang siap pakai, harus dites dahulu sebelum digunakan. Pengujian ini dilakukan dengan White Box, 
Black Box, Basis Path, pengujian arsitektur dan lain-lain.

f) Evaluasi Sistem Pelanggan mengevaluasi apakah sistem yang sudah jadi sudah sesuai dengan yang diharapkan. Jika ya, langkah 7 dilakukan; jika tidak, ulangi langkah 4 dan 5.

g) Menggunakan sistem

Perangkat lunak yang telah diuji dan diterima pelanggan siap untuk digunakan.

\section{HASIL DAN PEMBAHASAN}

Pengaruh $\mathrm{pH}$ larutan pada tanaman hidroponik adalah pengaruh daya serap tanaman untuk menyerap unsur hara pada air. Pada $\mathrm{pH}$ larutan dibawah 6.0 (asam) jumlah ion $\mathrm{H}+$ yang terdapat pada larutan jumlahnya lebih tinggi daripada ion $\mathrm{OH}$-. Kondisi ini unsur hara makro seperti kalsium, magnesium dan fosfor akan terikat secara kimiawi sehingga sulit diserap oleh tanaman. Akibatnya tanaman akan tumbuh kerdil dan tidak dapat berproduksi dengan maksimal. Pada pH larutan nutrisi datas 7.0 (basa) berbanding terbalik dengan larutan nutrisi yang bersifat asam, pada kondisi ini unsur hara mikro seperti tembaga, mangan, seng, dan besi akan terikat secara kimiawi sehingga tidak dapat diserap oleh tanaman. Akibatnya tanaman mengalami defisiensi unsur hara, dan pertumbuhannya akan cepat mati. Sehingga daripada itu diperlukan kondisi pH larutan yang bersifat netral yaitu berkisar 6.0 - 7.0. Pada pH larutan netral unsur hara makro maupun mikro tidak mengalami pengikatan unsur hara, pada kondisi ini tanaman hidroponik dapat tumbuh dan berprodouksi dengan maksimal, usia tanaman juga lebih panjang atau maksimal sesuai dengan jenis tanamannya. Pada kondisi netral tumbuhan dapat menyerap unsur hara mikro maupun makro yang dibutuhkan dengan baik. Pemberian larutan nutrisi berdasarkan nilai EC (Electrical Conductivity) dapat mempengaruhi pertumbuhan dan hasil beberapa tanaman contohnya pada tanaman bayam pada hidroponik sistem rakit apung (Floating Hydroponics System), karena terdapat nilai EC yang menunjukkan hasil tertinggi. Selain itu proses penguapan air (evaporasi) menjadi masalah tersendiri pada hidroponik. Maka diperlukan sistem kontrol untuk melakukan pengisian air otomatis jika volume air pada tandon tempat penyimpan air kurang. Suhu air nutrisi juga tak kalah penting dalam hidroponik. Dengan suhu yang ideal, tanaman dapat menyerap unsur hara dengan maksimal sehingga dapat tumbuh dengan baik. Suhu air ideal berkisar 25 derajat sampai 29 derajat celcius.

\section{a) Cara Kerja}

Di saat alat dihidupkan maka NodeMCU akan otomatis terkoneksi di hotspot wifi yang sudah diatur alamat dan pasword \& token yang sama pada pemberi hotspot, setelah terhubung maka buka aplikasi blynk pada smartphone lalu cek apakah sudah terhubung dapat di lihat pada gambar berikut.

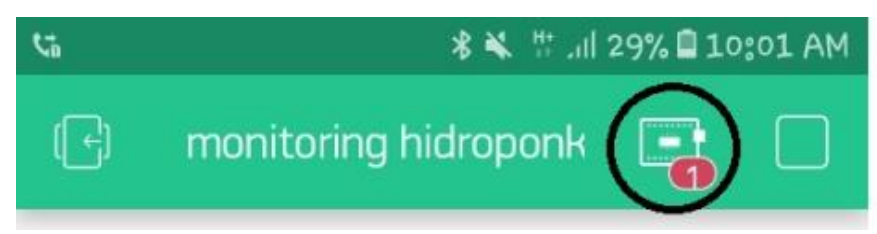

Gambar 3 Indikator 
Jika masih terdapat simbol angka 1 maka aplikasi blynk dan wifi belum terkoneksi, dan apabila simbol angka 1 sudah hilang maka aplikasi blynk dan wifi sudah pasti terkoneksi.
Apabila perangkat sudah terkoneksi semua maka selanjutnya aplikasi blynk android akan menampilkan data sensor DHT11, Water Level, LDR, pH meter. Dapat dilihat pada gambar berikut.

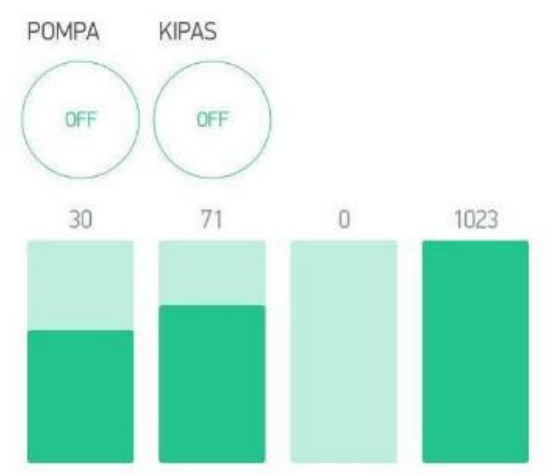

Gambar 4 Tampilan gauge dan button pada aplikasi blynk

Terdapat tampilan Gauge ada empat yang masing-masing berbeda fungsi untuk yang paling kiri menampilkan angka suhu, kelembapan, ketinggian air, dan intensitas cahaya. Dan terdapat 2 button yang berfungsi untuk menyalakan pompa dan kipas.
A. Proses pendeteksian suhu.

Sensor DHT11 akan mengirimkan sinyal digital ke NodeMCU dan di konversikan menjadi nilai angka suhu dan kelembaban ruangan, yang akan di tampilkan di aplikasi blynk android berikut tampilannya.

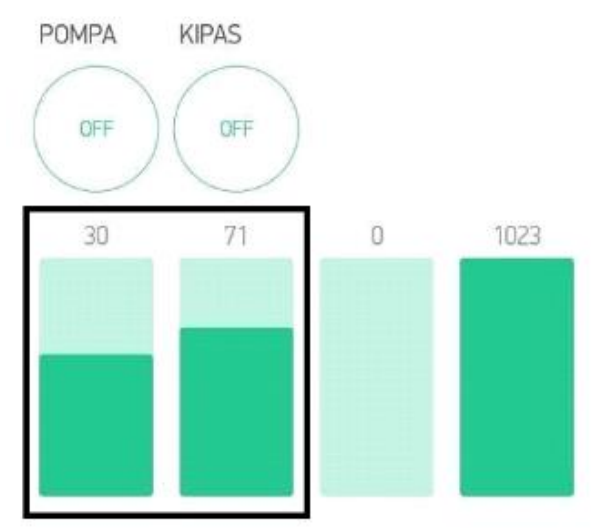

Gambar 5 Tampilan Suhu dan Kelembaban pada aplikasi blynk

Apabila suhu lebih dari $29^{\circ} \mathrm{C}$ maka kipas akan menyala untuk mendinginkan ruangan pada tanaman hidroponik.
B. Proses pendeteksian cahaya

Sensor LDR akan mengirimkan sinyal digital ke NodeMCU dan di konversikan menjadi nilai angka tertentu, yang akan di tampilkan di aplikasi blynk android berikut tampilannya. 


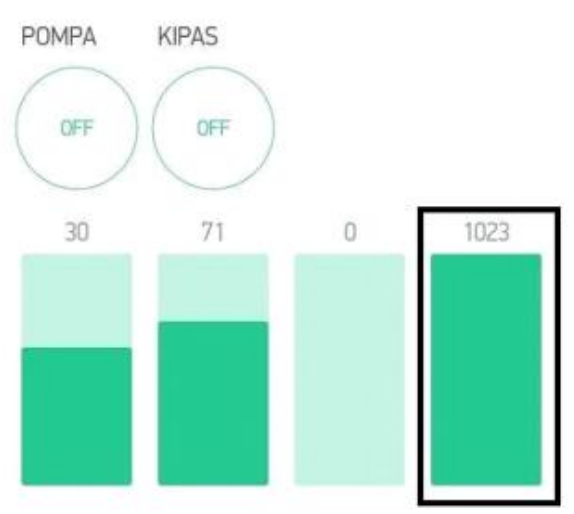

Gambar 6 Tampilan Intensitas cahaya pada aplikasi blynk

Apabila intensitas cahaya kurang dari 400 maka lampu akan menyala untuk memberi cahaya pada tanaman hidroponik.

C. Pengukuran kadar $\mathrm{pH}$ air pada bak penampungan air.
Sensor pH meter akan mengirimkan sinyal analog ke arduino dan di konversikan menjadi nilai angka tertentu, yang akan di tampilkan pada layar LCD berikut tampilannya.

Gambar 7 Tampilan kadar pH pada bak penampungan air

D. Proses pendeteksian ketinggian air pada bak penampungan air.

Sensor Water Level akan mengirimkan sinyal analog ke NodeMCU dan di konversikan menjadi nilai angka tertentu, yang akan di tampilkan di aplikasi blynk android berikut tampilannya.

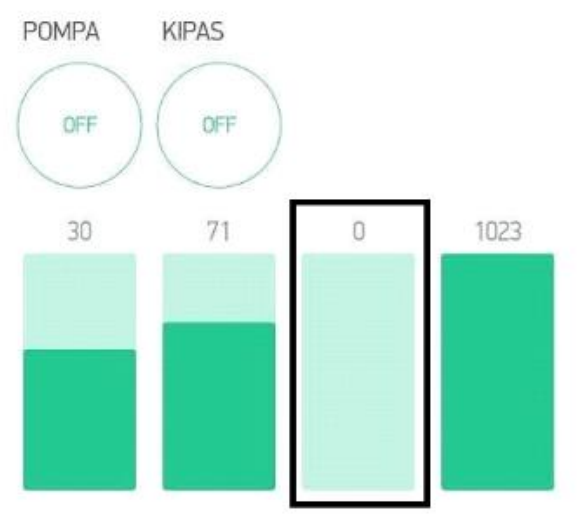

Gambar 8 Tampilan banyaknya air pada bak penampungan pada aplikasi blynk 
Apabila air di bak penampungan kurang dari $2 \mathrm{~cm}$ maka harus ditambahkan air yang sudah dicampur dengan nutrisi sampai batas ukur maksimal yaitu $5 \mathrm{~cm}$.

\subsection{Gambar Konstruksi}

Rancang bangun tempat hidroponik dengan sistem DFT dimana terdapat 2 pipa paralon yang digunakan untuk meletakan tanaman hidroponik agar dapat menyerap air dan nutrisi yang mengalir dan bak sebagai tempat penampungan air + nutrisi.

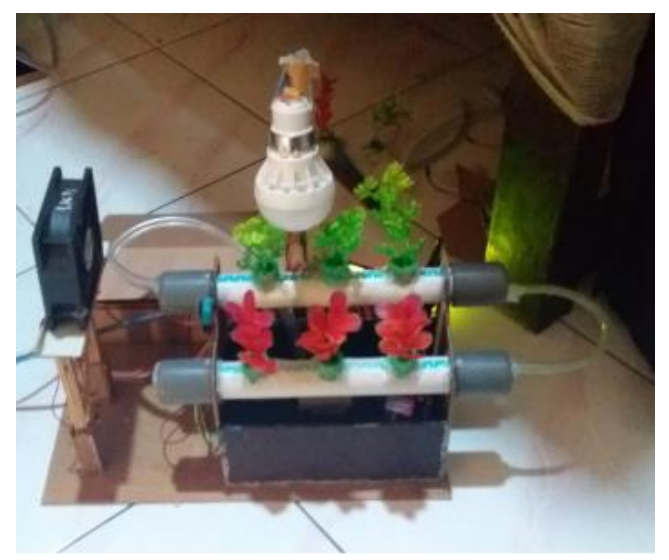

Gambar 9 Gambar kontruksi hidroponik

\subsection{Hasil Uji Coba}

A. Proses Pengujian sensor LDR dan Relay dengan Lampu DC $12 \mathrm{v}$

Pada Proses Pengujian sensor LDR digunakan aktuator berupa relay dan Lampu DC 12v untuk mengatur pencahayaan di tanaman Hidroponik DFT. Relay berfungsi sebagai fungsi logika.
Apabila sensor LDR di beri cahaya maka lampu akan mati, dan monitor di aplikasi blynk akan menunjukan tingkat persentase penuh, dan bila sensor LDR dalam ruangan yang gelap maka lampu akan menyala dan pada monitor di aplikasi blynk akan menunjukkan tingkat persentase 0 .

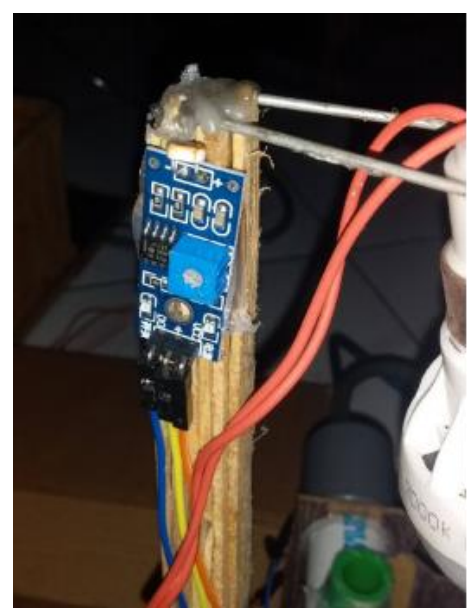

Gambar 10 Letak sensor LDR 


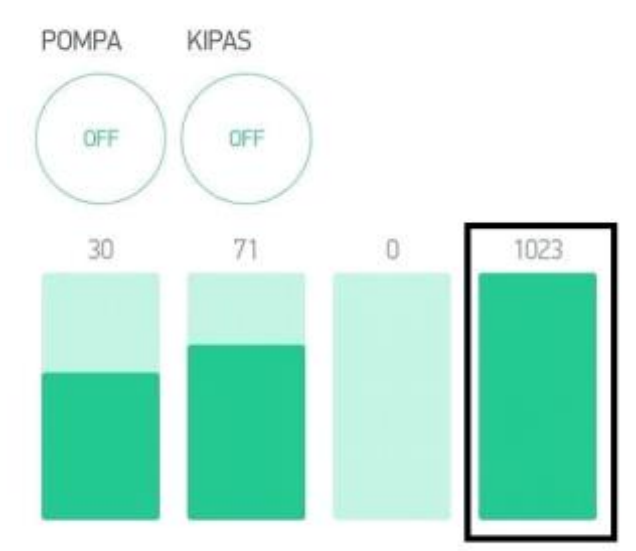

Gambar 11 Tampilan Intensitas cahaya pada aplikasi blynk

\section{B. Proses Pengujian sensor DHT11}

Sensor suhu DHT11 sebagai Sensor suhu yang berfungsi mendeteksi suhu pada lingkungan hidroponik. Sensor suhu DHT11 akan diprogram dengan setpoint tertentu sesuai kebutuhan suhu yang diperlukan sayuran agar dapat tumbuh dengan maksimal.

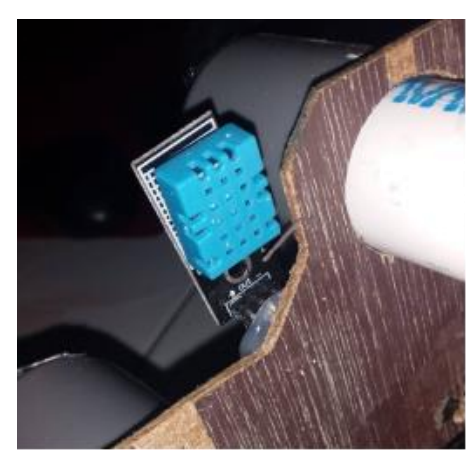

Gambar 12 Letak sensor DHT11

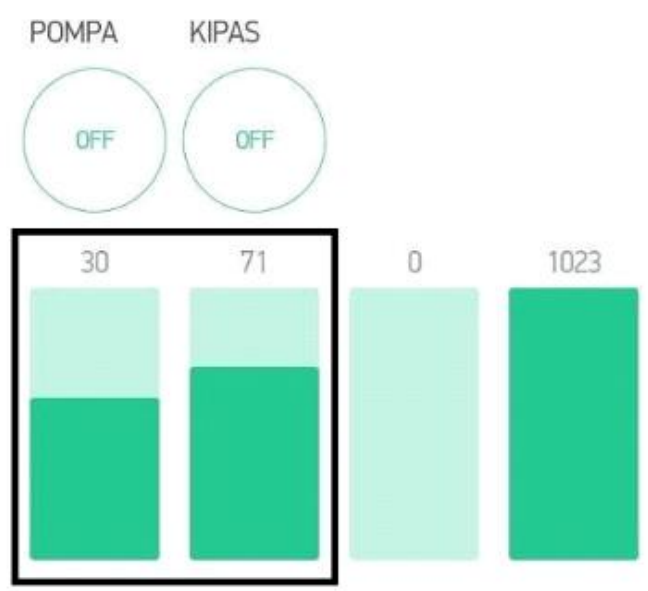

Gambar 13 Tampilan Suhu dan Kelembaban pada aplikasi blynk 
Tabel 1 Hasil Pengujian Sensor DHT11

\begin{tabular}{|c|c|c|c|}
\hline No & Waktu & Suhu & Kelembaban \\
\hline 1 & 9.00 & $29^{\circ} \mathrm{C}$ & $71 \%$ \\
\hline 2 & 9.30 & $29^{\circ} \mathrm{C}$ & $70 \%$ \\
\hline 3 & 10.00 & $30^{\circ} \mathrm{C}$ & $73 \%$ \\
\hline 4 & 10.30 & $30^{\circ} \mathrm{C}$ & $72 \%$ \\
\hline 5 & 11.00 & $31^{\circ} \mathrm{C}$ & $74 \%$ \\
\hline 6 & 11.30 & $31^{\circ} \mathrm{C}$ & $76 \%$ \\
\hline 7 & 12.00 & $33^{\circ} \mathrm{C}$ & $74 \%$ \\
\hline
\end{tabular}

C. Proses Pengujian Sensor Water Level

Sensor Water Level sebagai Sensor yang berfungsi mendeteksi kondisi bertujuan untuk menguji keluaran ketinggian air. Pengujian sensor ini sensor.

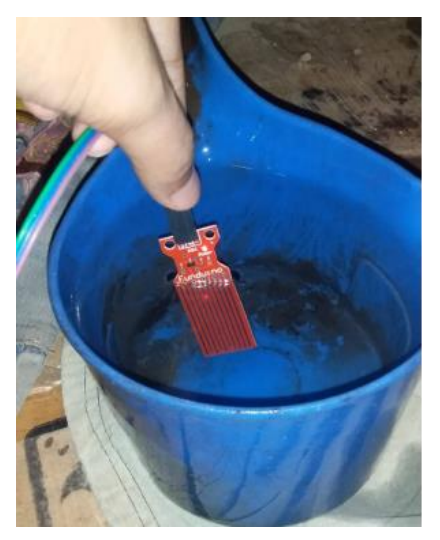

Gambar 14 Pengujian sensor Water Level

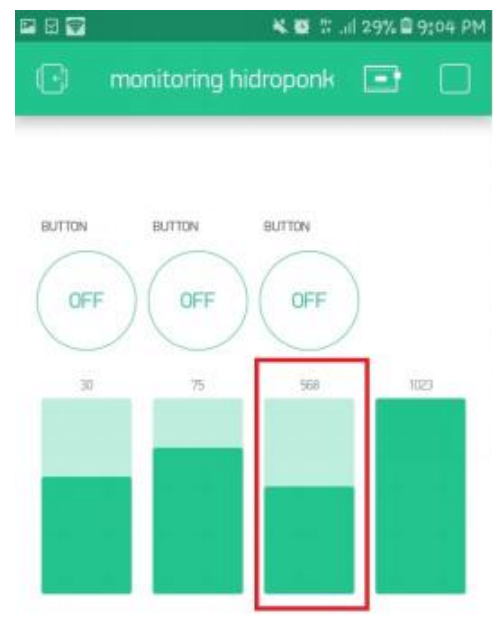

Gambar 15 Hasil tampilan pada aplikasi blynk 
D. Proses Pengujian sensor pH Meter

Pada penelitian ini digunakan Sensor $\mathrm{pH}$ sebagai Sensor pendeteksi kadar $\mathrm{pH}$ air di dalam bak reservior.

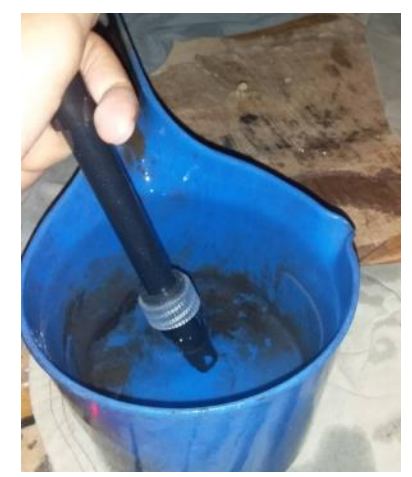

Gambar 16 Pengujian sensor $\mathrm{pH}$ meter

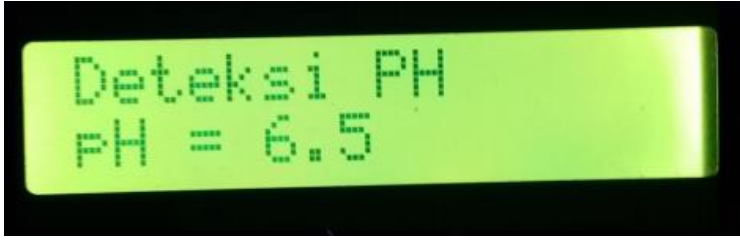

Gambar 17 Hasil tampilan dari sensor pH meter di LCD

Pengujian sensor $\mathrm{pH}$ bertujuan untuk mengkalibrasi sensor $\mathrm{pH}$ yang digunakan. Kalibrasi sensor digunakan untuk menentukan konversi nilai keluaran sensor yang berupa nilai ADC sebesar 10 bit ke dalam nilai kadar $\mathrm{pH}$. Penentuan konversi dilakukan dengan cara mengukur kadar $\mathrm{pH}$ menggunakan alat $\mathrm{pH}$ meter.
E. Proses Pengujian Relay dengan Kipas DC 12v

Proses Pengujian Relay digunakan aktuator berupa relay dan Kipas DC $12 \mathrm{v}$ untuk mengatur suhu di tanaman Hidroponik DFT. Relay berfungsi sebagai fungsi logika. Pada gambar 18 Menunjukkan pengujian modul relay dengan kipas DC menggunakan pengkondisian On dan Off pada modul relay

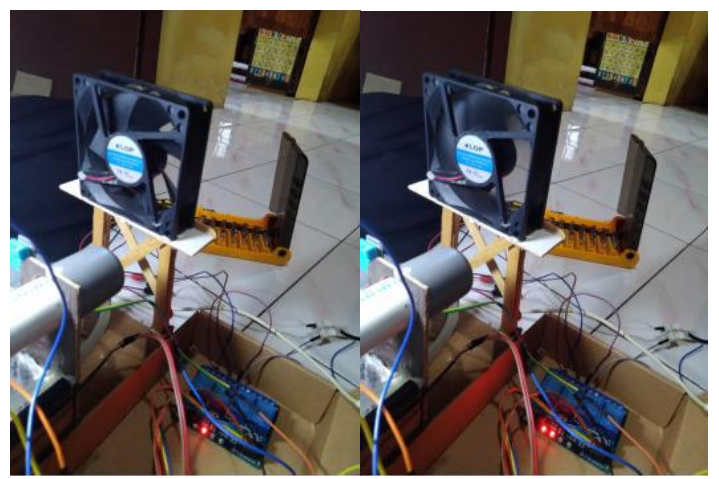

Gambar 18 Pengujian Relay dan Kipas DC 12v (a) kondisi LOW (b) kondisi HIGH 


\section{KESIMPULAN}

Dari uraian rangkaian proses pembuatan dan pengujian yang telah dilakukan dapat ditarik beberapa kesimpulan penting dalam kaitannya pada perancangan alat ini antara lain :

a) Aplikasi blynk di android memiliki fungsi sebagai interface monitoring sensor dan kontrol aktuator pada hidroponik. Pengujian sistem aplikasi blynk di android dengan melakukan komunikasi data secara realtime memperoleh presentase keberhasilan 90\%, dikarenakan ada beberapa sensor yang belum sepenuhnya akurat $100 \%$.

b) Pengujian pada masing-masing sensor juga bekerja dengan semestinya, seperti sensor DHT11 untuk pengukuran suhu, sensor Water Level untuk pengukuran ketinggian air nutrisi, Sensor $\mathrm{pH}$ meter untuk mengukur kadar $\mathrm{pH}$ di bak penampungan air, dan sensor LDR untuk mendeteksi intensitas cahaya, relay untuk mengontrol cahaya dan pompa air. 


\section{REFERENSI}

Anang Masduki. 2017. Hidroponik Sebagai Sarana Pemanfaatan Lahan Sempitdi DusunRandubelang, Bangunharjo, Sewon. Bantul. Jurnal Pemberdayaan, Vol.1, No. 2.

Chrisyantar Hasiholan. 2018.Pengembangan Teknologi Informasi dan Ilmu Komputer. Kabupaten bogor. e-ISSN: 2548-964X.

Hannif Izzatul Islam. 2016. Sistem Kendali Suhu Dan Pemantauan Kelembaban Udara Menggunakan Sensor Dht22. Kabupaten Bogor.Vol V.

Ibadarrohman, Nur Sultan Salahuddin, Anacostiana Kowanda. 2018. Sistem Kontrol dan Monitoring Hidroponik berbasis Android. Universitas Gunadarma Depok. STMIK ATMA LUHUR Pangkalpinang.

Jaenal Arifin, Intan Erlita Dewanti, Danny Kurnianto. 2017.Prototipe Pendingin Perangkat Telekomunikasi Sumber Arus DC Menggunakan Smartphone. Purwokerto. Media Elektrika, Vol. 10, No. 1.

Rosdiana, Muhammad Shofan. 2020. Pembuatan Aplikasi Monitoring Tanaman Hidroponik Otomatis Dengan Koneksi Wifi Berbasis Arduino. Universitas Gunadarma Depok.

Sitorus, N. B. (2017). Pendeteksian Ph Air Menggunakan Sensor Ph Meter V1.1 Berbasis Arduino Nano, Universitas Islam Negeri Sunan Gunung Djati Bandung.

Yuga Hadfridar Putra, Dedi Triyanto, Suhardi. 2018. Sistem Pemantauan dan Pengendalian Nutrisi, Suhu, dan Tinggi Air Pada Pertanian Hidroponik Berbasis Website. Universitas Tanjungpura Pontianak. Jurnal Coding, Sistem Komputer Untan Vol. 06, No. 03.

Wahyu Adi Prayitno, Adharul Muttaqin, Dahnial Syauqy. 2017. Sistem Monitoring Suhu, Kelembaban, dan Pengendali Penyiraman Tanaman Hidroponik menggunakan Blynk Android. Universitas Brawijaya. Jurnal Pengembangan Teknologi Informasi dan Ilmu Komputer, Vol. 1, No. 4. 